378.4.096 (477.83-25): 911.3:33

\author{
- блій \\ ввівський н ціон льний університет імені в н \\ вул. . орошенк , 41, м. ввів, 79000, кр їн
}

озкрито ет пи ст новлення і розвитку к федри економічної і соці льної геогр фії геогр фічного ф культету ьвівського н ціон льного університету імені в н $\mathrm{p}$ нк як н укового осередк ьвівської суспільно-геогр фічної школи. х р ктеризов но особливості дослідження теоретичних, методологічних, методичних т прикл дних проблем суспільної геогр фії з г лом і

хідного регіону зокрем . исвітлено зв'язки к федри з н вЧ льними т проектними з кл д ми кр їни і кр їн вропи т мерики.

лючові слов : н уков суспільно-геогр фічн школ, ст новлення і розвиток к федри, комплексно-регіон льний н прямок, міжг лузеві комплекси, геогр фічне укр їнозн вство, н укові зв'язки к федри.

федр економічної і соці льної геогр фії орг нізов н 3 н к зом з ступник н ркому освіти кр їнської у грудні 1944 р. ктично роботу поч л 1945/1946 н. p. 3 приходом сюди її першого з відув ч - к нд. геогр. н ук, доц. . щенк (1908-1984).

1984-1990 pр. функції з відув чів к федри виконув ли почергово доценти . робецький (1984-1986), . он к (1986-1988) т проф. . с ст вний (1988-1990). 1990 р. к федрою керує проф. блій.

о 1988 р. це бул к федр економічної геогр фії. он ст л сп дкоємницею к федри геогр фії, що бул створен у 1882-1883 н. р., н якій поряд з визн чними польськими вченими . ем ном (1840-1917) т . омером (1871-1954), н пос ді прив т-доцент пр цюв в доктор філософії С. удницький (1877-1937). к федрі підготовлено двох перших укр їнських докторів геогр фії: . еличк (1893) т . удницького (1901). ут з кл дено фунд мент льні основи н ціон льної геогр фічної, у тім числі суспільно-геогр фічної н уки ( . удницький. инішня геогр фія, ьвів, 1905) т геогр фічного укр їнон вств . міжвоєнний період н ціон льно-укр їнські студії н к федрі були перерв ні вн слідок політики окуп ційного режиму. ентром суспільно-геогр фічної думки ст ло укове тов риство ім. евченк ( . убійович, . теп нів, . гоновський, . едів, . еринович т ін.). керівництвом проф. . убійович було вид но “ тляс кр їни й сумежних кр їв” (1937) т “ еогр фію укр їнських й сумежних земель” (1938). ими пр цями, т кож твором . теп нів “уч сний ьвів” (1943), з вершено короткотрив лий період ст новлення н ціон льної суспільної геогр фії і к ртогр фії з г лом.

р ці н зв них учених у р дянський період були з боронені. ільшість з цих н уковців репресов но ( . теп нів, . удницький, . еринович), ч стин ( . убійович, . едів, . есля т ін.) емігрув л в хідну вропу т мерику. 1940-1941 pp. при “перших совєт х” к федру геогр фії університету очолюв в визн чний укр їнсь-

(с) блій ., 2012 
кий геогр ф олянський (1892-1975), який 1944 р. емігрув в в ргентину. 19411944 pр. к федр не пр цюв л . 1944-1946 рр. до ольщі виїх ли польські вчені. еред них н йбільш відомими були . іргофер, . онсович т к ртогр ф . горч к.

ерсон льний скл д новоутвореної к федри економічної геогр фії н поч тку їі розвитку (1944-1956) був сформов ний м йже винятково із н уковців, скеров них до ьвов зі сходу кр їни, - перев жно випускників рківського університету ( . щенко, . ільбер, . в ричевський, . уленко; . ільбер пр цюв в систентом к федри геогр фії ще у 1940-1941рр.). диними пр цівник ми місцевого походження були . теп нів (короткий термін погодинно ст рший викл д ч) т геодезист . умін (ст рший л бор нт). прикінці $1940-$ н поч тку 1950-х років сюди були скеров ні . уговой (н роджений н рянщині) т . уцький із осковського університету (н роджений у икол єві). середини 1950 - поч тку 1960-х років сюди прийшли вихідці із з хідних обл стей кр їни: . ст вний (1955), . блій (1958), . робецький (1961) (рис. 1).

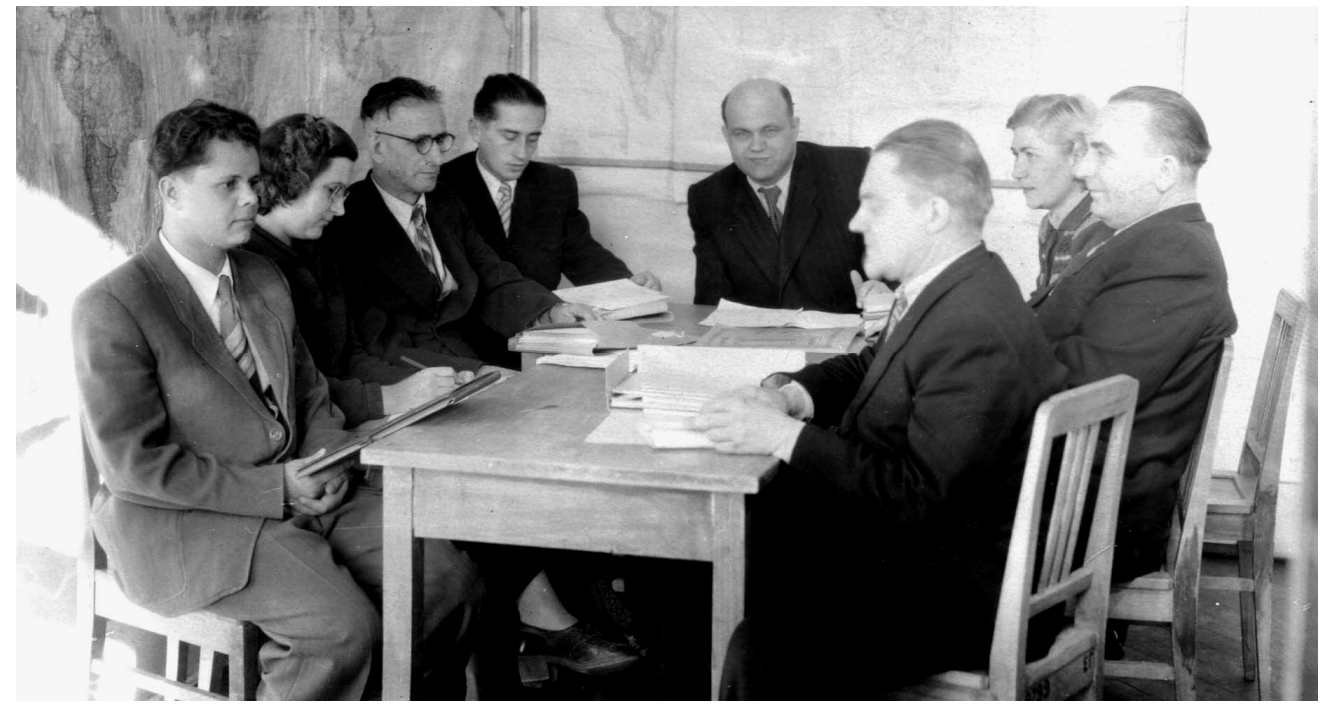

ис. 1. сід ння к федри економічної геогр фії (1957): сидять злів н говой, ст. л б. . иков, доц. - уцький, доц. . ст вний, доц. . щенко (з відув ч), ст. викл. . велко, ст. викл. . в ричевський, ст. л б. . умін.

пізніші роки к дровий скл д к федри поповнюв вся перев жно з її випускників через спір нтуру і доктор нтуру. ершим спір нтом був . уговой (піврічн спір нтур у 1963 р.); д лі - . блій (1961-1965), . он к (1963-1966), т кож до 1984 . оротун, . ксимов , . нісімов , . ед шківськ , . ілецький, . ниш, - л х, . льський, доктор нт ми . блій (піврічн доктор нтур 1976-1977) т . он к (1978-1980) (рис. 2).

инішній викл д цький скл д к федри сформов ний головно у 80-90-х рок х

ст. епер н к федрі пр цюють 18 осіб, з них дв професори, вісім доцентів (к ндид тів н ук), один систент к ндид т геогр фічних н ук, три систенти без н укових ступенів, три л бор нти, зокрем : з відув ч к федри, д-р геогр. н ук, проф. блій, 


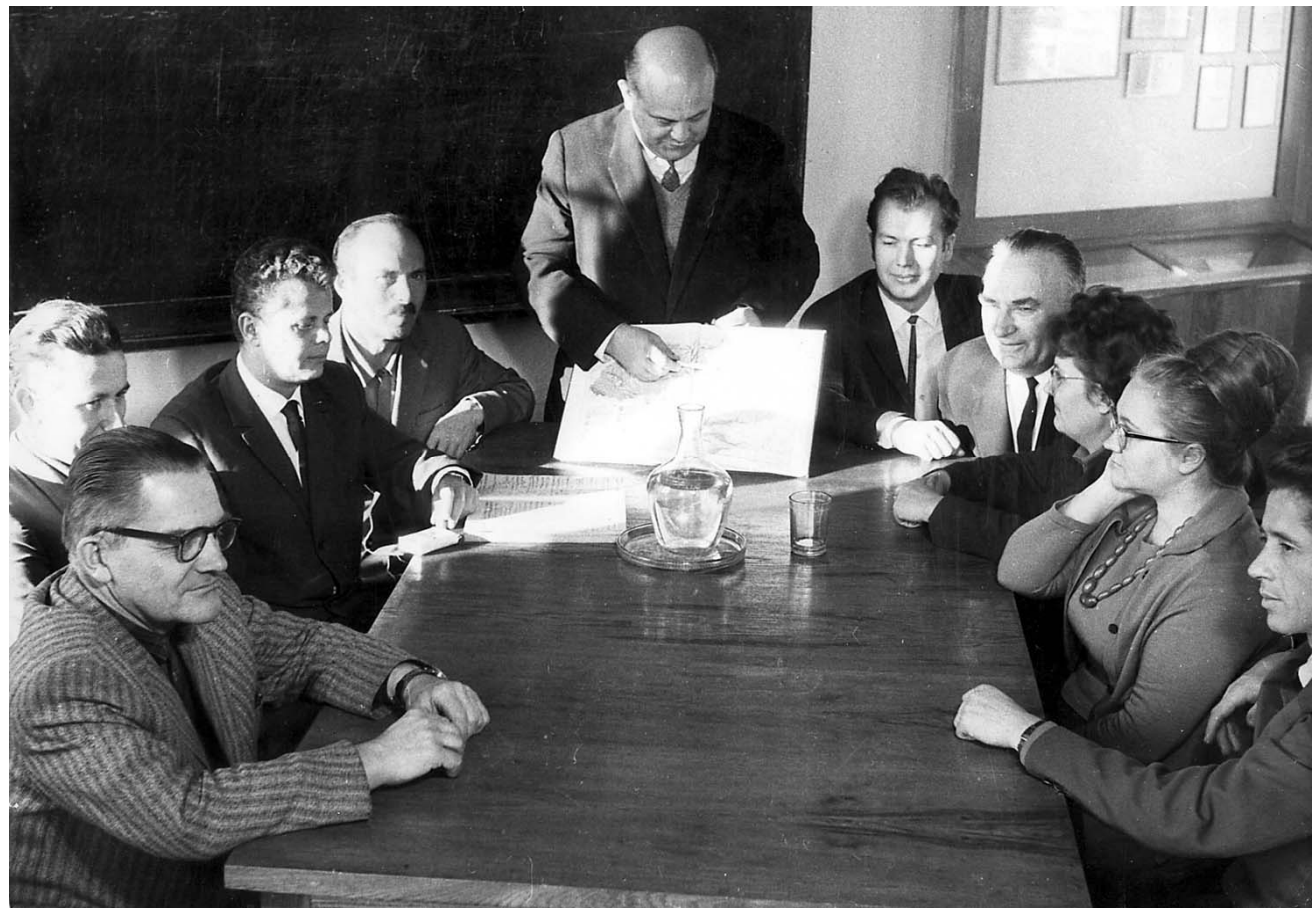

ис. 2. федр економічної геогр фії (1968): сидять злів н $n p$ во: ст. л б. . умін, ст. викл. - робецький, доц. - уговой, доц. - ільбер, доц. . щенко (з відув ч), в. о. доц. блій, доц. . в ричевський, ст. л б. . иков , ст. л б. . ксимов , ст. л б. . рич.

проф. . овенч к, доценти, к ндид ти н ук . ілецький, . ісьт к, . л х, рицевич, . удзеляк, . ниш, . узик, . тецький, до 2005 р. доцентом пр цюв л д-р екон. н ук . евчук). систент ми к федри є к нд-т геогр. н ук . мчур, . нд , . в х, . отик. спір нтурі к федри ст ном н 01.01.2011 р. н вч ються . p вець, . озинський, . конечн, . одісь, . молянінов, . рп , . енейко. 1990-2010-х рок х спір нтуру успішно з кінчили . удзеляк, . риняк, . тецький, . ісьт к, · ерх ч, . енюк, . иронюк, . ордун, . ом нів, . нця, . к б р , . олод, . бінськ , . еслюк, . уд кевич, . мчур, . одвірн . роки існув ння з вихов нців к федри підготовлено пон д 50 к ндид тів, близько 20 докторів н ук.

уково-дослідниьк діяльність. федр є н уковим ядром ьвівської суспільно-геогр фічної школи, що м є більш ніж столітню історію. кол $з$ поч тков н у 90-х рок х ст. першими доктор ми геогр фії . еличком т . удницьким. ерез неї до ругої світової війни пройшли відомі вчені . ордуб , . еринович, . гоновський, . теп нів, . ольницький, . убійович т ін. післявоєнний період iї предст вник ми, крім . щенк , ст ли випускники к федри, які пр цюв ли і пр цюють у вищих н вч льних т н уково-дослідних з кл д х ьвов, иєв , деси, ернополя, уцьк т ін. уттєвий внесок у теорію, методологію і методику суспільногеогр фічної н уки зробили випускники к федри, доктори н ук і професори . ремчишин, . ст вний, . істун, . опчієв, . гірн , . ст вецький, . ст вець- 
к , . етриг , . щук, . уцишин, . в нух, . льський, . ч н, . ушк р, блій, . зинін , . p вців, . р нгул, . блоцький, . ністрянський, . овенч к т ін.

оловним н уковим н прямом к федри є дослідження теоретичних і методичних проблем комплексної геопросторової орг ніз ції суспільств і його структурних ч стин (н селення, господ рство, соці льн, політичн, екологічн сфер тощо) у їхньому регіон льному, кр їнозн вчому т світовому вимір х. період 1944-2011 pp. н уков діяльність к федри пройшл декільк ет пів розвитку.

1. ет пі повоєнного “ст новлення” (1945-1953) к федр визн ч л головну тем тику н укової пр ці. ею ст л проблем геопросторової орг ніз ції сільського господ рств ьвівщини, кр їнських рп т і з хідних обл стей з г лом. ут вирізнялися головно пр ці . щенк . я тем переросл згодом у проблему територі льної орг ніз ції гропромислового комплексу (дисерт ції . в ричевського, . ілик , . оротун, . л х, . ниш), викон ння обл сних тл сів сільського господ рств ьвівської, рогобицької, к рп тської т в но- р нківської (тоді т нісл вівської) обл стей під орудою . щенк .

2. с середині 1950 першій половині 1960-х років в жливе місце посіл проблем геопросторової орг ніз ції промисловості, промислових комплексів, їхнього природноресурсного потенці лу (пр ці . ст вного і . угового з проблем розвитку ьвівськоолинського к м'яновугільного 6 сейну; н поч тку 80-х років - . льського (еколого-геогр фічні проблеми цього ж регіону)). ід другої половини 1960-х років інтенсивно вивч ли проблеми міжг лузевого територі льного комплексув ння, передусім лісо-, гропромислового т рекре ційного (дисерт ції . блія, . ілик , . ед шківської, . ниш, . ілецького, . узик , . ук , . л х). ідсумком інтенсивного розвитку цього н пряму ст ло вид ння книги . блія “ іжг лузеві територільні системи” (1975) т з хист ним докторської дисерт ції “ іжг лузеві територі льні комплекси: проблеми теорії і методики досліджень” (1978).

3. прикінці 60-х років ст. новою силою розвив вся комплексно-регіон льний н прям. хистили дисерт ції з проблем комплексоформув ння у ередк рп тті ( . робецький т . олос (випускник к федри)), хіднослов цького кр ю ( . он к), ернівецького економічного вузл ( . ис ренко). озвив лися дослідження н родон селення хідного регіону кр їни ( . щенко, . робецький, . ільбер, . нісімов ). ктом цього н пряму був з хист у 1971 р. докторської дисерт ції . щенком н тему: “ тл с розвитку господ рств з хідної ч стини кр їнської (з н йд вніших ч сів до 70-х років ст.)".

80-ті й под льші роки ст. к федр зробил в гомий внесок у розвиток теорії і методики дослідження економічної т соці льної геогр фії. уттєво поглиблено теоретичні основи територі льного комплексув ння ( . щенко, . ст вний, . блій), розроблено ієр рхію економічного р йонув ння ( . щенко), обгрунтов но концепцію міжг лузевих територі льних комплексів ( . блій), уведено в н уковий обіг поняття економічного вузл ( . щенко, . ис ренко), висунуто ідею гнучкої теритоpi льної орг ніз ції виробництв ( . блій), систем тизов но з кони $і$ з кономірносmi територі льної орг ніз ції виробництв ( . блій), розроблено н укові основи геопросторової орг ніз ції конкретних міжг лузевих територі льних комплексів ( . оротун, . ілик, . ед шківськ, . ілецький, . ниш, . л х), впров джено у н уковий обіг поняття територі льної економіко-екологічної проблеми і ситу ції ( . льський, . блій), обгрунтов но принципи геопросторовой орг ніз ції систем 
розселення ( . ст вецький, . блій); обгрунтов но геогр фічні імпер тиви екологічної діяльності ( . льський, . блій) т ін.

4. ісля здобуття кр їною нез лежності особливістю н укової діяльності к федри є інтенсивний розвиток нових н прямів: соці льно-, демо- і політико-геогр фічного, дослідження проблем історії укр їнської геогр фії і к ртогр фії, пр ця н д підготовкою нових підручників і н вч льних посібників, у тім числі словників-довідників для середніх і вищих н вч льних з кл дів. описовій геогр фії - це інтенсивний розвиток суспільно-геогр фічних укр їнозн вств, регіон лістики т кр єзн вств .

оці льно- і демогеогр фічні дослідження ст ли пріоритетними як н к федрі, т к і в усіх орг ніз ційних клітин х львівської суспільно-геогр фічної школи: пр ці професорів . ст вецької, - ст вного, . ч н , доктор економічних н ук . евчук, доц. . льської, . рицевич , . удзеляк, . уч бського, . озинського, . ерх ч, . ом нів, . к б ри, . к ч т ін. оловн проблем - дослідження геогр фічних процесів депопуляції н селення, змін у процес х розселення т мігр цій людності, деурб ніз ції (у контексті рецесії суспільного виробництв ), вивчення поширення злочинності ( . к 6 р ), соці льної стр тифік ції ( . ниш, . еслюк), геогр фічних спектів релігії ( . блій, . евчук, . ісьт к), культури (. овенч к, . уч бський) т освіти ( . тецький).

контексті ст новлення укр їнської нез лежної держ ви досліджув ли політикогеогр фічні й геополітичні проблеми (пр ці професорів . блія, . льського,

. ністрянського, . овенч К, доцентів . ісьт к, . іньк т ін.). озвив ється електор льн геогр фія ( . иронюк, . олод). ид но перші в кр їні н вч льні посібники і моногр фії, н укові розвідки (розділ “ олітико-геогр фічні особливості кр їни” у книзі з ред. . блія “ оці льно-економічн геогр фія кр їни” (1994, 1995, 2001) т моногр фія . ністрянського “ олітико-геогр фічні виміри кр їни” (2002)) (рис. 3).

нтенсифікув лись н укові пошуки з проблем історії н ціон льної геогр фії, зокрем суспільної. омітний внесок у період 1990-2010рр. зробили . блій, . овенч к, . ісьт к, . л х. ид но моногр фії про . удницького, . убійович , . теп нів, т кож книги пр ць . щенк, . еслі, . инявського, . довського, . теп нів, . ольницького, . убійович, . еринович, . олянського. снов но (2000) всеукр їнський ч сопис “сторія укр їнської геогр фії” (шеф-ред ктор блій, відповід льний ред ктор . ст вецький, з 2001 р. - . ст вецьк ), орг нізов но н укові всеукр їнські конференції, присвячені . удницькому, . убійовичу т . теп нів, з хищено ( . ісьт к, . евчишин) к ндид тські дисерт ції тощо.

еогр фічне укр їнозн вство і суспільно-геогр фічн регіон лістик ст ли головними в дослідженнях описової геогр фії. е: вивчення суспільної геогр фії кр їни 3 г лом і хідноукр їнського прикордонного регіону зокрем . ерше 3 них - це, передусім, підготовк т вид ння підручників і моногр фій із суспільної геогр фії кр їни, (посібники проф. . ст вного “ еогр фія кр їни” т “ оці льно-економічн геогр фія кр їни” групи вторів з ред. . блія), орг ніз ція міжн родних конференцій з проблем геогр фії кр їни (1994) т кту льних проблем геогр фічного укр їнозн вств (2000). кремою н уковою проблемою ст ло вивчення депресивних регіонів кр їни (. ст вний, . блій, . евчук, . нд т ін.). икон но регіон ліз цію кр їни. . ст вний обгрунтув в дев'ять економічних, . блій - шість соці льно-економічних р йонів кр їни. 


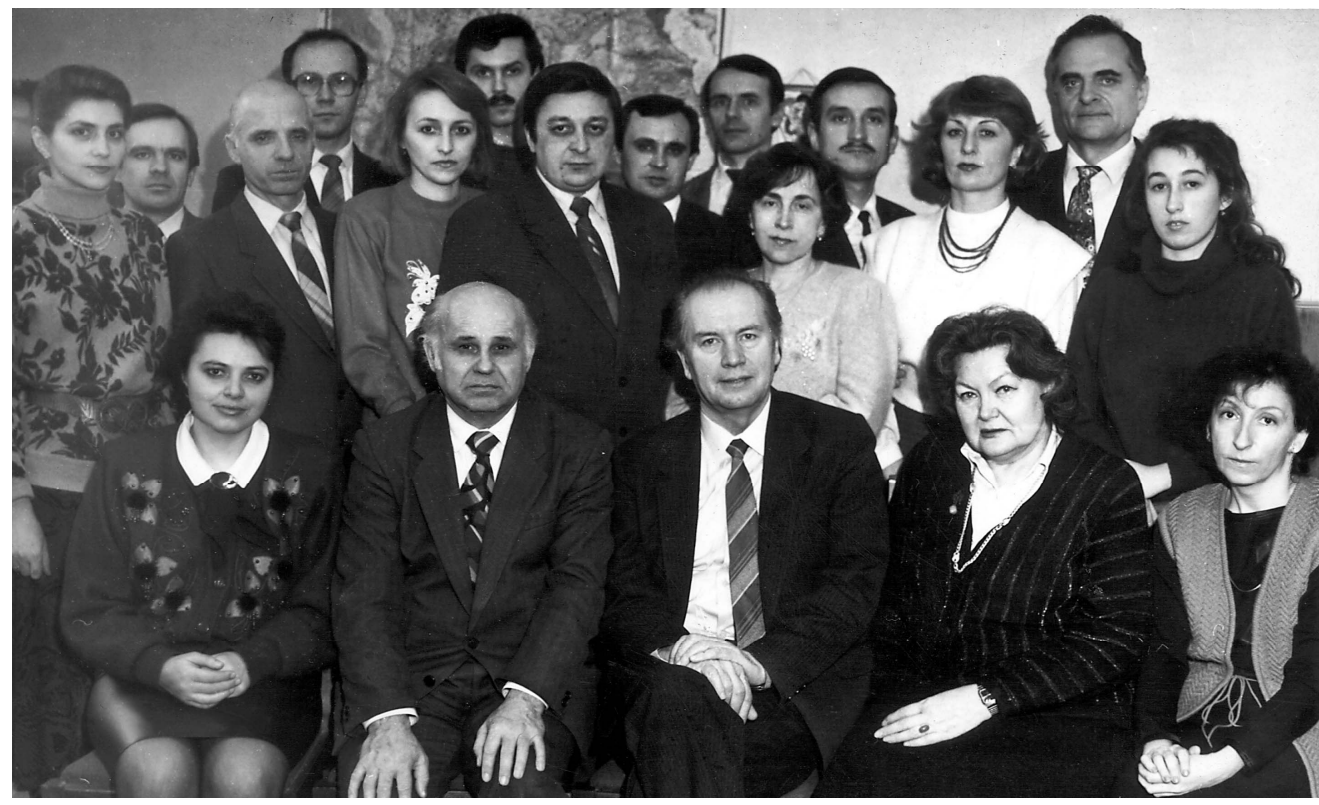

ис. 3. федр економічної і соці льної геогр фії (1994): сидять злів н $п р$ во. ст. л б. . ісьт к, доц. . он к, проф. . блій (з відув ч), доц. нісімов , ст. л б. . учв р ; стоять: сп. . орч к, мол. н ук. співроб. . рокопчук, доц. . ілецький, с. . в х, сп. - удзеляк, ст. л б. . ксимчук, с. . рицевич, с. . тецький, доц. . ук, ст. л б. . цях, доц. . овенч к, доц. . л х, доц. . узик, ст. л б. . ерх ч.

1990-2011 рр. к федр (рис. 4, див. вкл. 3) інтенсивно пр цюв л н д проблем ми суспільно-геогр фічного кр їнозн вств $i$ світозн вств : вид но моногр фії про окремі кр їни т регіони ( . ниш i . узик “ кономічн і соці льн геогр фія мерики”, . евчук “ інляндія” і “ ит й”, . ниш “р зилія”, “ оці льно-економічн геогр фія кр їн, що розвив ються”, . удзеляк і . м нців “ орв тія”, . удзеляк “еогр фія н се-лення”, . л х “ еогр фія н селення: словник-довідник”, . м нців і . едорусь “" кедонія”). кремою н уковою проблемою ост ннього десятиліття ст ло дослідження хідноукр їнського регіону т прикордонних єврорегіонів - рп тського і “ уг”.

г льн н уково-дослідн тем к федри економічної і соці льної геогр фії, яку виконують у меж х робочого ч су, - “ кономіко-, соці льно- і політико-геогр фічні проблеми хідноукр їнського прикордоння в умов х європейської інтегр ції і глоб ліз ції”. епер вон сформов н як “ успільно-геогр фічні проблеми з хідноукр їнського прикордоння”. вернено ув гу н природно-ресурсний, рекре ційний, пр цересурсний, тр нспортно-комунік ційний т історико-культурний потенці л, можливості тр нскордонного співробітництв 3 ольщею, горщиною, лов ччиною і умунією, створення міжн родних тр нспортних коридорів т ін. хищено дисерт ції . удзеляк, . енюком, . ордун, . убовичем т ін. федрою опубліков но збірник н укових пр ць “ кономіко-, соці льно- т еколого-геогр фічні проблеми розвитку хідноукр їнського р йону” (1994). озпоч то дослідження в ділянці кр єзн вств (книги . узик “н нягиничі” (2002), . блія “ ело н золотому оділлі: земля і люди” (2011)). 


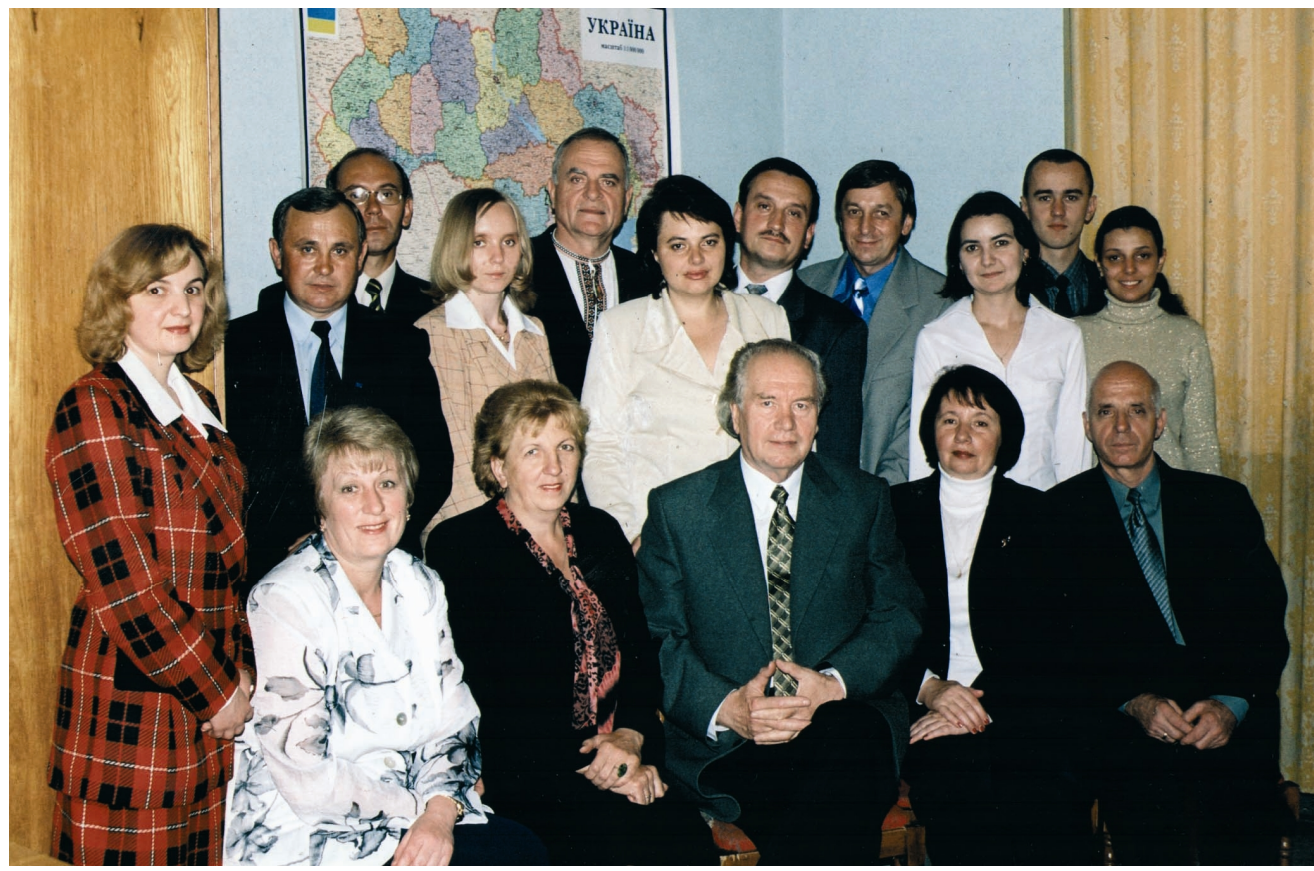

ис. 4. федр економічної і соці льної геогр фії (2004): сидять злів $н$ нр во: доц. . л х, доц. . евчук, проф. . блій (з відув ч), доц. . ниш, доц. . ілецький. тоять злів н пр во: ст. л б. . едорусь, доц. . тецький, с. . в х, с. . отик, доц. . узик, доц. . ісьт к, доц. . овенч к, доц. . рицевич, с. . нд , с. . нця, л б. . иц.

федр м є зн чний доробок у г лузі демо- і соці льно-економіко-геогр фічного $\kappa$ ртогр фув ння. ей н прям з поч тков ний . еличком i . удницьким т продовжений після війни . енком, т його учнями т сп дкоємцями ( . уговой, . блій, . ниш, . овенч к, . льський, . ісьт к т ін.). ід орудою . щенк у 50-х рок х ст. викон но декільк рукописних тл сів сільського господ рств з хідних обл стей ( к рп тської, в но- р нківської, рогобицької т ьвівської). першій половині 60-х років з господ рським договором із ьвівським р дн ргоспом викон но середньом сшт бну економічну к рту дміністр тивно-економічного р йону ( втор - щенко). . уговий виготовив тл с ьвівсько- олинського вугільного б сейну (1960-ті роки).

зл мі 80-90-х років ст. створено три фунд мент льні тл си соці льно-економічних комплексів ьвівської, в но- р нківської обл стей т м. ьвов (керівник проекту - блій). озгорнуто вид ння шкільних і кр єзн вчих тл сів ьвівської (1989), в но- р нківської (1990) т к рп тської (1991) обл стей, т кож “ тл с ьвівської обл сті” із серії “ оя тьківщин ” (з ред кцією . блія). 2012 р. вийшл пр ця “ ьвів: комплексний тл c”.

творено л бор торію комплексного тл сного к ртогр фув ння (керівник . p вець), у якій викон но к ртогр фічне моделюв ння еколого-медичної ситу ції у м. ьвові, підготовлено “ омплексний тл с ьвов ”. . рицевич ст в одним з вторів 
м тем тичного визн чення геогр фічного центру кр їни (с. p'янівк поблизу м. поли ерк ської обл.). використ нням комп’ютерних технологій к федр освоїл поєдн ння м тем тичних і к ртогр фічних методів моделюв ння.

mудентськ н уков робот . ід поч тку існув ння к федри студенти отримують н вички н укової пр ці, беручи ктивну уч сть у викон нні її н укової тем тики. ст ннім десятиріччям розвинулися різні форми уч сті студентів у н уковій роботі: ) студентські н укові гуртки (окремо двох перших курсів, якими керує . рицевич, i окремо ст рших курсів під орудою . л х); б) студентські н укові конференції. м тері л ми гурткової діяльності студенти виступ ють н звітних річних н укових конференціях к федри т ф культету, студентських н укових форум х в інших вищих н вч льних 3 кЛ д х.

ході викон ння госпдоговірних робіт, передусім тл сів обл сних регіонів і “ омплексного тл су ьвов ”, студенти третього-четвертого курсів бр ли уч сть у збир нні вихідних ст тистичних м тері лів, їхньому опр цюв нні, скл д нні р зом з н уковими керівник ми вторських оригін лів к рт. икон ні студент ми дипломні т м гістерські роботи м ють вихід у сферу пр ктики територі льного прогр мув ння т проектув ння.

туденти з йм ли т кі призові місця: . ельник (н конференції у уцькому держ вному пед гогічному університеті імені есі кр їнки, 2000, 2001), . нтилей (у иївському н ціон льному університеті імені р с евченк , 2000), . уд кевич (н економічному ф культеті ьвівського н ціон льного університету імені в н $\mathrm{p}$ нк 2003). они бр ли уч сть у сеукр їнських геогр фічних олімпі д $\mathrm{x}$ ( . нд , . еньків, . нця, . етрів, . м нців, . п нович, . ельник, . еглюк, . уд кевич). р щі студенти були резервом к федри для вступу в спір нтуру ( . ісьт к, . иронюк, . нд , . м нців, . нця, . ельник, . еглюк, . орзій, . одісь, . озинський, . конечн, . рп, . овк т ін.).

уково-орг ніз ційн діяльність. еред різних видів н уково-орг ніз ційної роботи к федри - орг ніз ція н укових конференцій, з'їздів, н р д т семін рів; з ходів н відзн чення ювілейних д т т в жливих н укових подій тощо, зокрем , н укових форумів у ьвові, иєві, ернівцях, ернополі, уцькут івному. жлив рольк федри в орг ніз ції всесоюзних н р д з проблем н селення і розселення у з хідних обл стях кр їни (1966), конференції з проблем розвитку кр їнських $\quad$ рп т (1968). 1987 р. орг нізов но з сід ння уково-методичної р ди іністерств вищої освіти з геогр фічної освіти.

нтенсифіков но пр цю в цьому н прямі н поч тку 90-х років ХХ ст. творчій співпр ці з ученими ернопільського пед гогічного інституту (тепер університету) проведено три конференції з проблем історії розвитку укр їнської геогр фії і к pтогр фії. о 100-річчя - убійович у ьвові орг нізов но міжн родну конференцію “ кту льні проблеми геогр фічного укр їнозн вств” (2000). 1994 р. к федр бр л ктивну уч сть у міжн родній конференції “ кту льні проблеми геогр фії кр їни” ( ьвів). зом 3 іншими к федр ми ф культету орг нізов но т кож конференцію до сторіччя (1982) т 120-річчя (2003) геогр фії у ьвівському університеті, у 2005 р. міжн родну конференцію до 60-річного ювілею к федри, 2008 р. - міжн родні семін ри до 100-ліття . щенк і 125-ліття . еринович , 2010 р. - до 110-річчя проф. . убійович .

федр бул т кож співорг ніз тором вид ння всеукр їнського ч сопису “ сторія укр їнської геогр фії” ( ернопіль; шеф-ред ктор . блій). . блій є членом ред- 
колегії ф хового ч сопису “ кр їнський геогр фічний журн л” ( иїв), “егіон льн економік ” т “ оціогум ніт рні проблеми людини” ( ьвів), “ сопис соці льно-економічної геогр фії” ( рків), “ існик ” ( ьвів), “ рп тський кр й” ( в но- р нківськ),

р цівник ми к федри ініційов но вст новлення меморі льних т блиць у місцях пр ці . удницького, . убійович т . теп нів ( ьвів), трив є пр ця н д відкриттям П м'ятник . убійовичу у ьвові.

ідготовк геогр фів-суспільствозн вців. федр інтенсивно веде підготовку висококв ліфіков них ф хівців - 6 к л врів, спеці лістів і м гістрів 3 спеці льністю 7.070500 “ кономічн і соці льн геогр фія” (спеці лісти), 8.070500 “ кономічн і соці льн геогр фія” (м гістри), т кож віднед вн з спеці ліз цією 7.070501 “ олітичн геогр фія і геополітик" (спеці лісти) т 8.0705001 “ олітичн геогр фія і геополітик " (м гістри). 1944-2011 рр. к федр вихов л пон д 650 ф хівців економікогеогр фів різних кв ліфік ційних рівнів. он бере уч сть у підготовці економістів і філософів, відповідно, н економічному і філософському ф культет х ьвівського н ціон льного університету імені в н $\mathrm{p}$ нК .

пеці льність “ кономічн і соці льн геогр фія” для к федри є тр диційною. одноч с 2000 р. 3 к федрою з кріплено підготовку ф хівців зі спеці ліз ції “ олітичн геогр фія і кр їнозн вство”. дн к тоді пр вові кти не д ли змоги н вч ти н к федрі ф хівців більше ніж однієї спеці ліз ції. ому підготовку з спеці ліз цією “олітичн геогр фія і кр їнозн вство” було припинено. 2007/2008 н. р. ï відновлено в модифіков ній формі “ олітичн геогр фія і геополітик ”.

вч льні пл ни з підготовки геогр фів-суспільствозн вців регулярно перегляд ють і вдоскон люють з ур хув нням нових тенденцій у розвитку н уки т вимог. овим н зл мі тисячоліть ст ло інтенсивне впров дження у н вч льні пл ни і н укові пошуки інформ ційних технологій. огляду н це переглянуто перелік спецкурсів. ведено спецкурси “ омп’ютерні інформ ційні технології”, “ еоінформ ційні системи”, “ у суспільно-геогр фічних дослідженнях", “нформ тик у політичній геогр фії і кр їнозн встві”. епер жодн курсов чи дипломн робот не обходиться без використ ння комп'ютерної техніки, з стосув ння м тем тичних методів і моделей, інформ ційних інтернет-технологій. творюють умови для впров дження дист нційних методів н вч ння.

1962-1966 рр. к федр з безпечув л викл д ння основ економічної геогр фії у уцькому з г льнон уковому ф культеті. відкриттям у ьвівському університеті економічного ф культету (1966) тут орг нізов но курс “ кономічної геогр фії з рубіжних кр їн”, який згодом змінено н “ озміщення продуктивних сил і економік регіонів”, який викл д ють т кож для економічних спеці льностей в інституті післядипломної освіти університету. крім того, к федр з безпечує викл д ння спецкурсу “ снови демогр фії”н філософському ф культеті.

туденти, які спеці лізуються н к федрі, проходять різні види пр ктик - н вч льних і виробничих (м гістри - систентську). окрем , н першому курсі н вч льним пл ном передб чено кільк пр ктик для з кріплення і з стосув ння зн нь $з$ геодезії і к ртогр фії: топогр фічн (дв тижні) і міжзон льн з г льногеогр фічн із суспільногеогр фічним підрозділом (дв тижні). другому курсі $€$ комплексн фізико-економіко-геогр фічн пр ктик (шість тижнів), н третьому курсі - виробнич пр ктик (шість тижнів). туденти пр цюють н 63 х пр ктики, у тому числі в уст нов х держ вної ст тистики (р йонних і обл сних), з кл д $\mathrm{x}$ територі льного розпл нув ння $\mathrm{i}$ 
прогнозув ння. четвертому курсі передб чено т кож чотиритижневу пед гогічну пр ктику. п'ятому курсі студенти м ють м гістерську (м гістри) т переддипломну (спеці лісти) пр ктику, які є продовженням виробничої і, з звич й, з тією ж тем тикою.

м тері л х виробничої, переддипломної т м гістерської пр ктик студенти пишуть курсові, дипломні і м гістерські роботи. ві ост нні з хищ ють перед ерж вною екз мен ційною комісією. ороку декільк робіт рекомендує відзн чити і впров дити у пр ктику територі льного упр вління.

руслі ініційов них перетворень ьвівського н ціон льного університету к федр здійснює перехід до олонського процесу підготовки висококв ліфіков них ф хівцівгеогр фів.

в'язки із середніми і вищими н вч льними з кл дми. федр підтримує тісні зв'язки із середньою і вищою школою, що поляг ють у т кому 1) уч сть у післядипломній підготовці ф хівців суспільно-геогр фів; м є ктивні стосунки із ьвівським обл сним н уково-методичним інститутом освіти; 2) підготовк і вид ння н вч льних посібників і підручників для середньої т вищої геогр фічної освіти. уло вид но перші в кр їні н вч льні посібники “ оці льно-економічн геогр фія кр їни” (з грифом іносвіти і н уки кр їни з ред. . блія). н ступні роки опубліков но більше десяти н вч льних посібників і підручників: . блія, . евчук, . узик , . ниш, . удзеляк. озроблено і вид но декільк шкільних і шкільно-кр єзн вчих тл сів (з ред. . блія): ьвівської (1989), в но- р нківської (1990) т к рп тської (1991) обл стей, т кож тл си ьвівської обл сті із серії “ оя тьківщин ” (чотири вид ння у 2000-2005 рр.) т н вч льних посібників. 2011 р. у вид вництві “ ртогр фія” ( иїв) поб чить світ к ртозбірня “ ьвів: комплексний тл с" (близько 250 к рт, к ртосхем і к ртоїдів) т ін.

лени к федри беруть ктивну уч сть у проведенні обл сних учнівських олімпі д 3 геогр фії т розробляють з вд ння для них т пр цюють з член ми лої к демії н ук кр їни. ороку випускники цієї к демії ст ють студент ми геогр фічного ф культету. он д 25 років геогр фічним відділом керує проф. . блій. ля середньої школи ьвівщини р зом 3 бл сним н уково-методичним інститутом освіти підготовлено н вч льно-методичний посібник “ ьвівськ обл сть” ( . блій т . ерх ч). чителям ьвівщини члени к федри регулярно чит ють лекції з теоретичних, прикл дних і методичних проблем суспільної геогр фії.

в'язки з пл новими і проектними орг ніз ціями. 3 мовлення пл нових і проектних уст нов т орг ніз цій к федр викон л кільк н укових розробок і обгрунтув л пропозиції щодо н прямів соці льно-економічного розвитку окремих регіонів (обл стей, $\mathrm{p}$ йонів) т поселень 3 ходу кр їни.

договором із ьвівським р дн ргоспом викон но “ кономічну к рту ьвівського дміністр тивно-економічного р йону” (1963р., н уковий керівник проекту щенко). федр двічі обгрунтовув л пропозиції до енер льних пл нів розвитку м. ьвов ( . щенко, . блій, . евчук). окрем , для розв'яз ння тр нспортної проблеми м. ьвов з пропонов но збудув ти систему ходових м гістр лей, т кож переходу з екстенсивного до інтенсивного шляху водопост ч ння ьвов . евчук розробил шк лу в ртісних оцінок земель ьвов т околиць. ьвівському істопроекті створено філію (1988), де студенти к федри проходили виробничу і переддипломну пр ктику. 
відув ч к федри . блій пр цюв в у комісіях, створених при бл сній дміністр ції ьвівської обл. т міському голові ьвов, беручи уч сть в обгрунтув нні перспектив розвитку обл сті й міст .

роки нез лежності кр їни к федр 3 домовленістю із вл дними структур ми ворівського р-ну ьвівської обл. розробил прогр му подол ння його депресивності.

в'язки з н ви льними і н уковими інституціями вропи т мерики. ост нні 10-15 років розвив ється співробітництво з 6 г тьм з рубіжними н уковими інституціями. орми співробітництв різном нітні: уч сть співробітників к федри і з рубіжних учених у н укових форум х, орг нізов них однією зі сторін бо сумісно; н укове ст жув ння, обмінні студентські пр ктики, спільне вид ння н укових пр ць, розроблення н уково-пр ктичних проектів т ін. еогр фія зв'язків охоплює н вч льні і н укові з кл ди ольщі, лов ччини, імеччини, , н ди, р нції, інляндії, оciï.

собливо плідн співпр ця з н уково-н вч льними з кл д ми ольщі, зокрем , 3 к федрою економічної геогр фії юблінського університету ім. рії юрі- клодовської (спільні дослідження укр їнської і польської н укової сп дщини, ре ліз ція проекту тл су укр їнсько-польського прикордоння, обмінн пр ктик студентів, уч сть у н укових форум х). н логічн співпр ця з ученими-геогр ф ми рш вського (н укове ст жув ння) т геллонського (викон ння спільних тем з проблем розвитку $р$ ков i ьвов ), роцл вського (ст жув ння, конференції), лупського (ст жув ння) університетів. - евчук успішно співпр цюв л з ученими ельсінського університету ( інляндія). публіков но пр цю . евчук т . ррев р “ інляндія: соці льно-економіко-геогр фічн х рктеристик” (2001). . нісімов, . удзеляк т . иронюк успішно співпр цюв ли з ученими ейпцизького університету з проблем ктивіз ції депресивних регіонів гірничо-видобувної промисловості. зом із ученими встрійського нституту хідної і івденно- хідної вропи ( ідень) з відув ч к федри . блій співпр цюв в у підготовці “ тл су хідної і івденно- хідної вропи” (19981999) (спів втор к рти “ іжн родні тр кційно-туристичні об'єкти ередньої і івденно- хідної вропи”).

чені к федри освоюють нгломовний н уковий простір через уч сть у н укових конференціях ( . евчук), ст жув ння ( . блій), перекл д книг ( . блій). руслі освітньої прогр ми кр їнської федер ції мерики (директор - професор емплського університету у іл дельфії ндер ) викон но спільний проект - вид ння перекл дного підручник мерик нських вторів “ еогр фія: світи, регіони, концепти” 3 вторською уч стю . блія із його н уковою ред кцією.

існий зв'язок к федри $з$ індзорським університетом ( . тебельським, учнем . убійович (обмін літер турою, н вч льними прогр м ми, спільні вид ння т ін.). р диційними є зв'язки т кож з ученими осійської едер ції, зокрем московськими, петербурзькими і пермськими (уч сть у конференціях, обмін новинк ми н укової літер тури, рецензув ння н вч льних посібників і моногр фій, н вч льні пр ктики).

нтенсифікув лися зв'язки з відділ ми укового тов риств ім. евченк у вропі ( риж), мериці ( шингтон), н ді ( оронто, тт в ). пільними зусиллями вид но пр ці геогр фів . убійович , . теп нів, . довського, . ольницького, . удницького, . еринович , . олянського т ін.

еобхідне удоскон лення структури к федри шляхом розвитку в ній, крім соці льно-економічної спеці ліз ції, т кож спеці ліз ції “ олітичн геогр фія і геополі- 
тик ”, реорг ніз ції н уково-дослідної л бор торії комплексного тл сного к ртогр фув ння.

m ття: н дійшл до редколегії 08.10.2011

прийнят до друку 22.11.2011

\section{SCIENTIFIC AND SCIENTIFIC-ORGANIZATIONAL ACTIVITIES OF THE DEPARTMENT OF ECONOMIC AND SOCIAL GEOGRAPHY}

\section{O. Shabliy}

Ivan Franko National University of Lviv, . Doroshenko St., 41, UA - 79000 Lviv, Ukraine

Stages of formation and development of the Department of Economic and Social Geography of the Faculty of Geography of Ivan Franko National University of Lviv as a scientific center of Lviv humangeographical school are revealed. Special features of the theoretical, methodological, methodical and applied problems' research of human geography in general and in Western region in particular are characterized. The Department connections with the education and design institutions from the countries of Europe and America are explained.

Key words: scientific human-geographical school, the formation and development of the Department, complex-regional direction, inter-branch complexes, geographical studies of Ukraine, scientific connections of the Department.

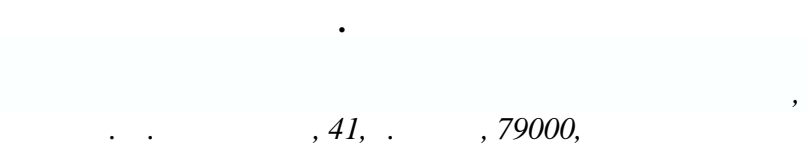

скрыто эт пы ст новления и р звития к федры экономической и соци льной геогр фии геогр фического ф культет ьвовского н цион льного университет имени в н $\mathrm{p}$ нко к к н учного ядр львовской общественно-геогр фической школы. х $\mathrm{p}$ ктеризов но особенности исследов ния теоретических, методологических, методических и прикл дных проблем общественной геогр фии в целом и п дного регион кр ины в ч стности; связи к федры с учебными и проектными з ведениями кр ины и стр н вропы и мерики.

лючевые слов : н учн я общественно-геогр фическ я школ, ст новление и р звитие к федры, комплексно-регион льное н пр вление, межотр слевые комплексы, геогр фическое укр иноведение, н учные связи к федры. 